\title{
IDENTIFICATION OF GROUND WATER RECHARGE POTENTIAL ZONE FOR WATERSHED USING GIS AND REMOTE SENSING
}

\author{
H.D.Bhave \\ Civil Engineering Department, RCOEM, Nagpur, India \\ Y.B.Katpatal \\ Civil Engineering Department, VNIT , Nagpur, India \\ Dr.A.M.Pophare \\ Department of Geology, RTMNU, Nagpur, India
}

\begin{abstract}
This study is aimed to identify the groundwater recharge potential zones, to be used for better and improved groundwater resources. The thematic layers considered in this study are geomorphology, soil, land use-land cover, slope (\%), lithology and lineament, which are prepared using satellite imagery and other conventional data. Each hydrogeomorphic unit is evaluated for its recharge potential and suitably a map showing such groundwater recharge potential zones for appropriate recharge is prepared. The thematic layers are first digitized from satellite imagery, supported by ancillary data such as topo-sheets and field investigation data, finally all thematic layers were generated. Using ArcGIS software the groundwater recharge potential zones for the study area are identified and maps are generated showing groundwater recharge potential zones namely 'least suitable', 'moderately suitable' and 'most suitable' on knowledge based on weighted factors.
\end{abstract}

Keywords: Remote sensing, GIS, Weighted factors, Thematic maps, Imagery

Cite this Article: H.D.Bhave,. Y.B.Katpatal and Dr.A.M.Pophare, Identification of Ground Water Recharge Potential Zone for Watershed using Gis And Remote Sensing, International Journal of Advanced Research in Engineering and Technology, 10(1), 2019, pp 121-135.

http://iaeme.com/Home/issue/IJARET?Volume=10\&Issue $=1$

\section{INTRODUCTION}

Groundwater is most preferred source of water for meeting domestic, industrial and agricultural requirements, due to its longer resident time in the ground, low level of contamination, wide distribution, and availability within the reach of the end user. Even the existing wells are getting dried-up due to depletion of ground water table as the natural recharge is not sufficient. 
Groundwater recharge is a basic pre-requisite for efficient groundwater resource development and management, which is particularly vital for India with widely prevalent semi-arid and arid climates. In case, the natural recharge is not sufficient, it has to be met through artificial recharge. Appropriate locations for constructing artificial recharge structures are studied scientifically.

Using remote sensing and geographic information system (GIS) it is possible to take number of different thematic maps of the same area and overlay them on top of one another to form a new integrated layer

Groundwater recharge refers to the entry of water from the unsaturated zone below the water table surface, together with the associated flow from the water table within the saturated zone. Groundwater recharge occurs when water flows past the groundwater level and infiltrates into the saturated zone. Field investigations help to explain the process of groundwater recharge and evaluate the spatial-temporal difference in the study area. However, these field investigations often focus on a single affecting factor or an indirect site-specific detail for groundwater recharge, reducing the reliability of the investigations. In recent times remote sensing and geographic information system technique is proved to be a cost effective and time saving tool to produce valuable data on geomorphology, geology, land use land cover, slope, lineament, lithology, etc., which helps to decipher groundwater recharge potential zones. Many researchers such as Chaudhary et al. (1996), Rajat C. Mishra et al. (2010), Dr. Jyoti Sarup et al. (2011) have used the approach of remote sensing and GIS for identification of groundwater potential zones and exploration of groundwater with locating the artificial recharge sites. Akram Javed et al. (2009), Narendra et al. (2013) have used remote sensing and GIS techniques for delineation of groundwater potential zones. Jothiprakash V. et al. (2003), Balachandar D. et al. (2010), Binay Kumar et al. (2011), Nepal C. Mondal et al. (2011) have used the remote sensing and GIS technique for generation of groundwater recharge zones for the improvement and development of groundwater for the region. Pinak. et al. (2015) have applied Geo spatial technique for RWH potential. J. Brema et al. (2012.) have used GIS for identification of sites suitable for artificial recharging and groundwater flow modelling.Integrated approach of remote sensing and GIS can provide the appropriate platform for convergent analysis of divergent datasets for decision making. RS-GIS is not only used for mapping and planning of groundwater resources but also used for efficient and cost effective use of a region.

\section{STUDY AREA}

An admeasuring area of 335.6 sq.km of Aam River watershed, Umred Tahsil, Nagpur district, Maharashtra, is selected for the research. The study area extends north $20.761 \mathrm{dd}$ to $20.968 \mathrm{dd}$ and east $79.102 \mathrm{dd}$ to $79.3905 \mathrm{dd}$, which lies in Survey of India topo-sheet bearing nos.55P/1, $55 \mathrm{P} / 5$. It covers three watersheds viz., WGA2A, WG3A and WG4A. Aam River originates as a major tributary of Wainganga river with elevation of $280 \mathrm{~m}$ above msl. The study area is selected by observing the water level depth and rainfall data. The problem of groundwater recharge can be solved by artificial measures. The study area is shown in fig.1.and fig.2.The Water level data and Rainfall data are shown in table1 and table2 below. 
Identification of Ground Water Recharge Potential Zone for Watershed using Gis And Remote Sensing

Table 1 Water Level Data

\begin{tabular}{|c|c|c|c|c|c|c|c|}
\hline \multirow{3}{*}{ Station } & \multicolumn{2}{|c|}{$\begin{array}{l}\text { Water leavel } 2011 \\
\text { mbgl }\end{array}$} & \multirow{3}{*}{$\begin{array}{l}\text { Fiuctuatio } \\
\qquad \mathbf{n}(\mathbf{m})\end{array}$} & \multicolumn{4}{|c|}{ Water leavel Trend 2001-2010 (m/y) } \\
\hline & \multirow{2}{*}{$\begin{array}{c}\text { Pre } \\
\text { monsoon }\end{array}$} & \multirow{2}{*}{$\begin{array}{c}\text { Post } \\
\text { mansoon }\end{array}$} & & \multicolumn{2}{|c|}{ premonsoon } & \multicolumn{2}{|c|}{ postmansoon } \\
\hline & & & & Rise & Fall & Rise & Fall \\
\hline Amgaon & 4.9 & 3.2 & 1.7 & & & & \\
\hline Bela2 & 4.05 & 3.9 & 0.15 & & & & \\
\hline Besur & 0 & & 0 & & 0.8687 & 0.0560 & \\
\hline Borkhdi & 6.75 & 3.7 & 3.05 & & 0.1456 & 0.0186 & \\
\hline Chacher & 7.34 & 2.5 & 4.48 & 0.0671 & & & 0.0019 \\
\hline Rohna & 5.1 & 4.6 & 0.5 & 0.5448 & & 0.5871 & \\
\hline Sathnaori & 15.9 & 9.2 & 6.7 & 0.1786 & & 0.1848 & \\
\hline $\begin{array}{l}\text { Satnaori } \\
\text { (Tola) }\end{array}$ & 9.1 & 7 & 2.1 & & & & \\
\hline Saoner & 0 & & 0 & 0.0975 & & 0.49 .4 & \\
\hline sawargaon & 9.4 & 9 & 0.4 & & & & \\
\hline Sirpur Toli & 4.25 & 3.9 & 0.35 & 0.0758 & & & 0.0028 \\
\hline Sivani & 5.25 & 2.2 & 3.05 & & 0.0579 & & 0.0081 \\
\hline Umrer & 0.8 & 0.6 & 0.2 & 0.3281 & & 0.4193 & \\
\hline Umrer(p1) & 4.5 & 3.7 & 0.8 & & & & \\
\hline Uti & 4.85 & 1.6 & 3.25 & 0.0459 & & 0.0155 & \\
\hline Wagholi & 7.2 & 1.7 & 5.5 & 0.1441 & & 0.1135 & \\
\hline Wardhamana & 4.25 & 0.6 & 3.65 & & 0.1232 & 0.0314 & \\
\hline
\end{tabular}


H.D.Bhave, Y.B.Katpatal and Dr.A.M.Pophare

Table 2 Rainfall Data

\begin{tabular}{|c|c|c|c|c|c|c|c|c|c|c|c|}
\hline Taluka & $\mathbf{2 0 0 2}$ & $\mathbf{2 0 0 3}$ & $\mathbf{2 0 0 4}$ & $\mathbf{2 0 0 5}$ & $\mathbf{2 0 0 6}$ & $\mathbf{2 0 0 7}$ & $\mathbf{2 0 0 8}$ & $\mathbf{2 0 0 9}$ & $\mathbf{2 0 1 0}$ & $\mathbf{2 0 1 1}$ & Average \\
\hline Nagpur City & 1176.1 & 1431.5 & 702.3 & 973.4 & 975.7 & 741 & 952.9 & 954.4 & 1395.3 & 879.4 & 1018.2 \\
\hline $\begin{array}{c}\text { Nagpur } \\
\text { Gramin }\end{array}$ & 966.7 & 1229 & 689 & 1274.7 & 1205.5 & 966.3 & 953.2 & 947.4 & 1494.7 & 913.8 & 1064.0 \\
\hline Kamthi & 1035.8 & 1208.7 & 707.1 & 1475.8 & 1178.2 & 1250 & 791.6 & 1032.6 & 1098.6 & 861.3 & 1059.5 \\
\hline Hingni & 479.2 & 770 & 583.3 & 920.4 & 814.9 & 806 & 683.1 & 724.7 & 942.2 & 814.8 & 753.9 \\
\hline Ramtek & 1101.3 & 822.5 & 733.9 & 1435.5 & 1133 & 1370.8 & 856.3 & 905.2 & 1184 & 885.1 & 1043.7 \\
\hline Parshiwani & 850.1 & 1056.9 & 858.4 & 1239.5 & 1106.2 & 878.8 & 1068.6 & 983.6 & 1086.6 & 1043.8 & 1017.3 \\
\hline Maudha & 904 & 1171.6 & 613.3 & 1679.1 & 1114.3 & 1030.9 & 814.1 & 1280.4 & 1520.5 & 1366.2 & 1151.2 \\
\hline Katol & 649.6 & 920.1 & 555.1 & 1092.3 & 937.4 & 1271.8 & 773.2 & 888.4 & 1027.9 & 801.8 & 891.8 \\
\hline Narkhed & 822.8 & 778 & 606.7 & 914.9 & 768.6 & 1281.3 & 671 & 954.1 & 1136.9 & 764.9 & 869.9 \\
\hline Sawner & 823.6 & 1063.6 & 312.6 & 1497.2 & 974.1 & 1209 & 873.6 & 941.6 & 1078.4 & 945.8 & 1022.0 \\
\hline Kalmeshwar & 740 & 1092.9 & 808.6 & 1320.9 & 916.4 & 1203.4 & 675.9 & 780.5 & 1180.5 & 855.2 & 957.4 \\
\hline Umrer & 846.2 & 1296.8 & 747.1 & 1856.3 & 1014.2 & 1464 & 1060.36 & 926.2 & 1551.2 & 887.1 & 1164.9 \\
\hline Bhiwapur & 923.3 & 1146.3 & 740.4 & 1431.2 & 1045.6 & 1341.8 & 853.2 & 993.2 & 1690.1 & 1088.4 & 1125.4 \\
\hline Kuhi & 859.2 & 1057.2 & 596.4 & 1543.8 & 828.6 & 1286 & 817.9 & 950.3 & 1291.5 & 1024.7 & 1025.6 \\
\hline Avserage & 869.9 & 1074.7 & 698.0 & 1332.5 & 1000.9 & 1146.9 & 846.7 & 947.4 & 1262.7 & 938.0 & 1011.8 \\
\hline
\end{tabular}

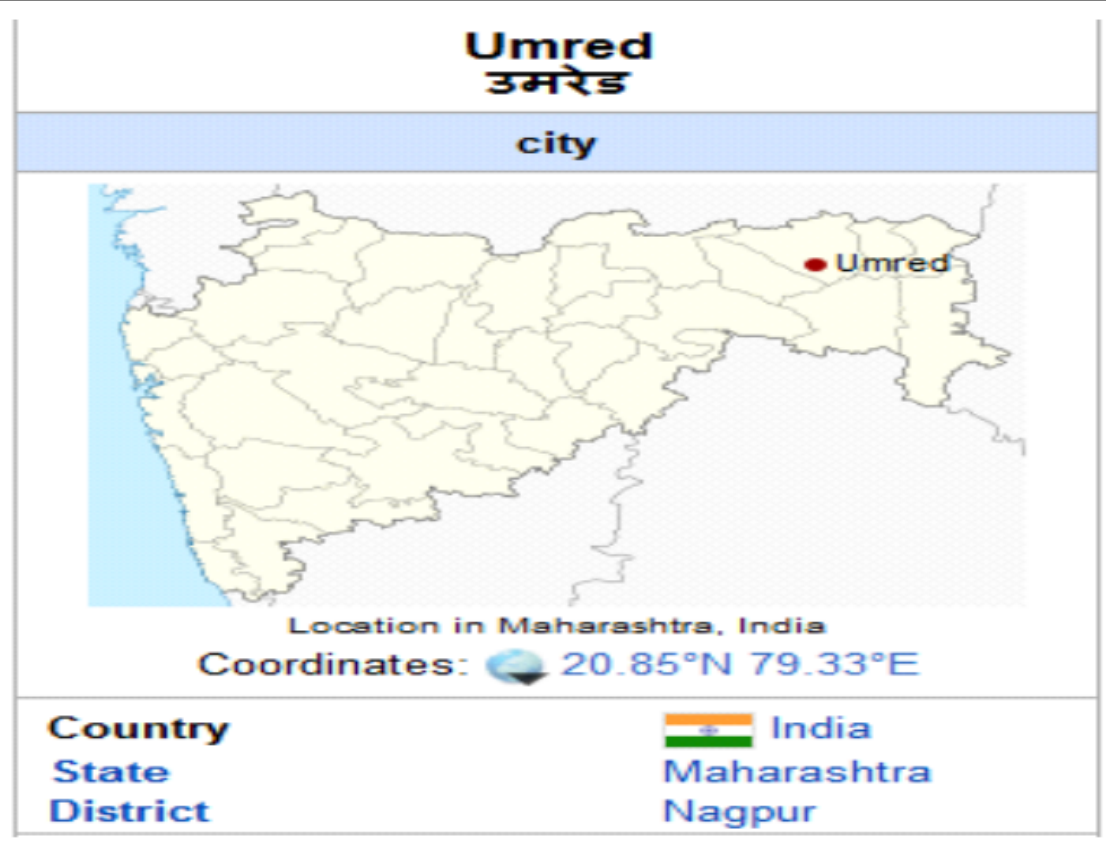

Figure 1 Study Area 


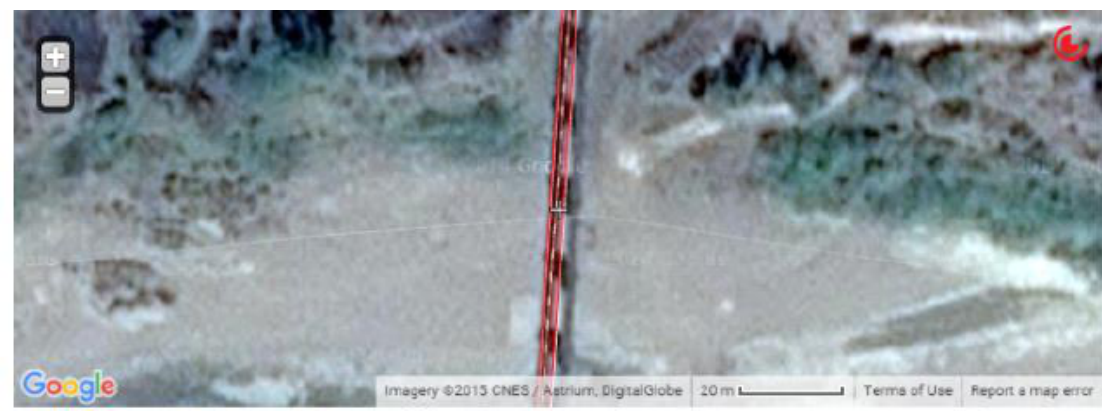

Nearby cities: Umred, Bhandara, Kamthi

Coordinates: $20^{\circ} 53^{\prime} 46^{\prime \prime} \mathrm{N} 79^{\circ} 22^{\prime} 11^{\prime \prime} \mathrm{E}$

Figure 2 Aam River

\section{MEHODOLOGY}

First SOI topo-sheets no. 55P/1, 55P/5 are geo-coded with the help of known ground control points (GCPs) on it. These geo-coded topo-sheets are then mosiaced to create the boundary map of study area with relevant details, in the form of shape file using ArcGIS software. Clipping operation is carried out for obtaining required details of study area from the mosiaced toposheets. Using map to image registration technique of Geomatica software image is geometrically rectified and registered with SOI topo-sheets on 1:50000 scale. The false colour composite (FCC) is generated from red, green and blue spectral bands (1,2 and 3). To enhance the satellite imagery linear, equalization and root enhancement techniques have been used for better interpretation of the geomorphological, soil, structural and other information for preparation of thematic maps. For digitization, editing, and topology creation, various features ArcGIS software has been used. The assignment of rank and weightage to different features/themes and classes was carried out. The integration of multi-thematic information is done to identify groundwater potential zones and to generate map.

The generated groundwater recharge potential map, is classified in three zones viz., 'Least suitable', 'moderately suitable' and 'most suitable'. This is verified with field data to ascertain the validity of the study conducted.

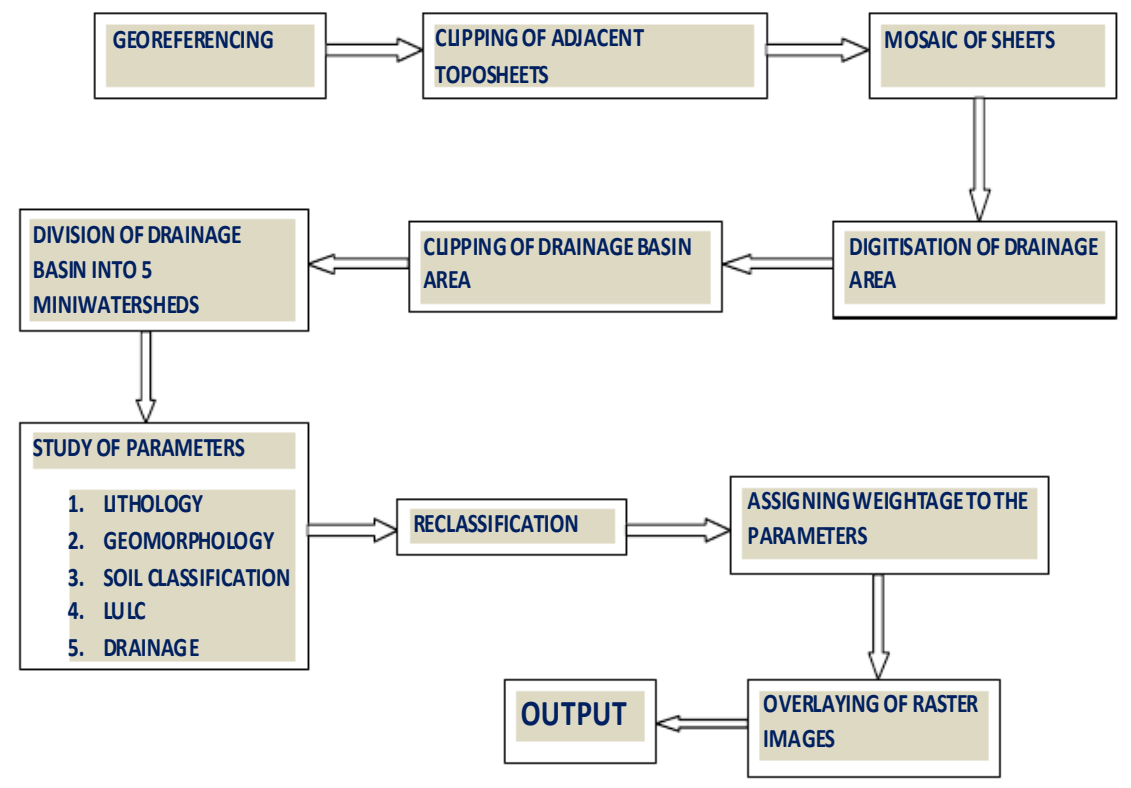

Figure 3 Schematic Diagram showing Methodology 


\section{ANALYSIS AND DISCUSSION}

\subsection{Slope}

The precipitous terrain causes rapid runoff and does not store water easily. Slope of any terrain is one of the factors allowing the infiltration of groundwater into subsurface or in other words groundwater recharge. In the gentle slope area, the surface runoff is slow allowing more time for rainwater to percolate, whereas, steep slope area facilitates high runoff allowing less residence time for rainwater to percolate and hence comparatively less infiltration. The slope map of the study area is derived from ASTER DEM $30 \mathrm{~m}$ and slope of the study area is classified into five classes, which is as per figure 4 below.

The ranks are assigned to the individual slope class, according to its respective influence of groundwater occurrence, holding and recharge, as per table 3 below.

\subsection{Geomorphology}

The identification and characterisation of various landforms and structural features in the study area was very important from geomorphological study point of view. Many of these features are favourable for occurrence and recharge of groundwater and are classified in terms of

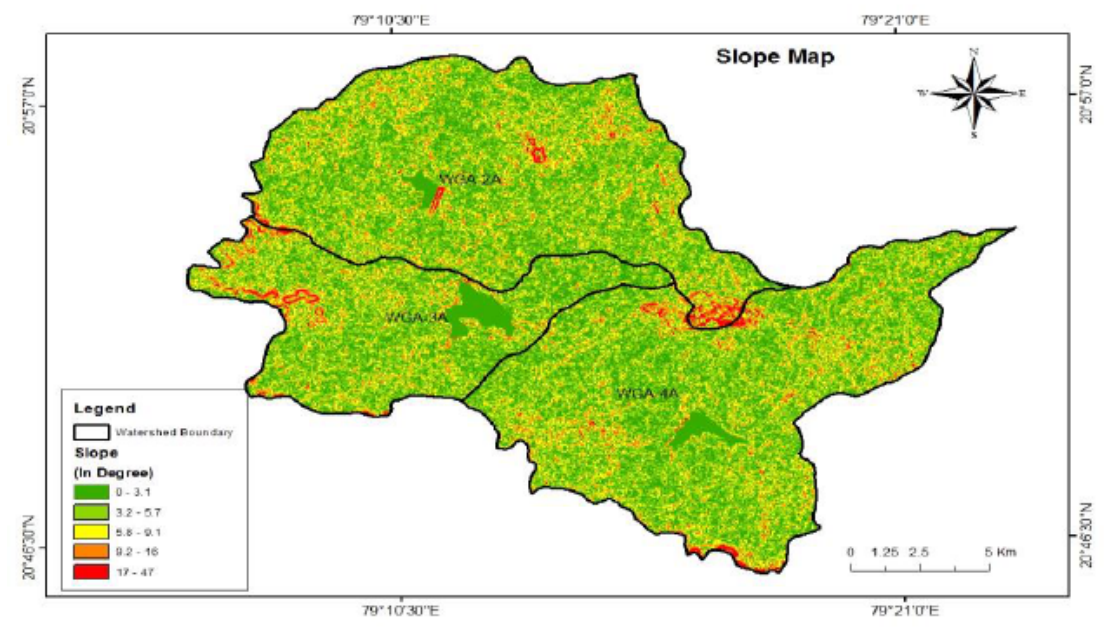

Figure 4 Ranking of Slope

Ground water recharge. Geomorphologic units are delineated based on the image characteristics such as tone, texture, shape, colour and associations. By overlapping the base map over the geo-coded FCC image, the geomorphologic units and landforms, the structural information and structural trend lines are incorporated. Structural hills are observed on southern east part of the study area, which are the linear or acute hills exhibiting definite trend lines and mostly act as runoff zones due to its sloping topography. This shows poor potentiality for groundwater occurrence and recharge. Butte is a small portion of land which has moderate high elevation compared to local surrounding land and having considerable slope due to which this also acts as runoff zone. This shows poor potential for ground water occurrence and recharge. Valleys are low lying depressions formed longitudinally along the streams or amongst the ridge portions, which shows excellent potential for groundwater occurrence and recharge. Burried pedi-plain are flat and smooth surface with shallow overburden and are usually crisscrossed by fractures / lineaments, faults, etc. and are considered to be good for groundwater occurrence and recharge. Pediplain is a broad gently sloping or nearly flat erosion surface or plain of low relief, typically developed by running water; it is considered as moderate for groundwater occurrence and recharge. By extraction of various classes of geomorphology, a thematic map 
Identification of Ground Water Recharge Potential Zone for Watershed using Gis And Remote Sensing

for geomorphology is generated as per figure 5 below. The ranks were assigned to the individual landform, according to its respective influence of groundwater occurrence, holding and recharge, as per table 4 below.

Table 3 Ranking of Slope

\begin{tabular}{|c|c|c|c|c|}
\hline $\begin{array}{c}\text { Sr. } \\
\text { no. }\end{array}$ & $\begin{array}{c}\text { Slope } \\
\text { (in } \\
\text { degrees) }\end{array}$ & Description & $\begin{array}{c}\text { Ranking } \\
\text { (in words) }\end{array}$ & $\begin{array}{c}\text { Ranking } \\
\text { (in numbers) }\end{array}$ \\
\hline 1. & $0-3.1$ & Nearly levelled & Good & 1 \\
\hline 2. & $3.2-5.7$ & Gently sloping & Moderate & 2 \\
\hline 3. & $5.8-9.1$ & $\begin{array}{c}\text { Moderately } \\
\text { sloping }\end{array}$ & Moderate & 2 \\
\hline 4. & $9.2-16$ & $\begin{array}{c}\text { Strongly } \\
\text { sloping }\end{array}$ & Poor & 3 \\
\hline 5. & $17-47$ & Steep sloping & Poor & 3 \\
\hline
\end{tabular}

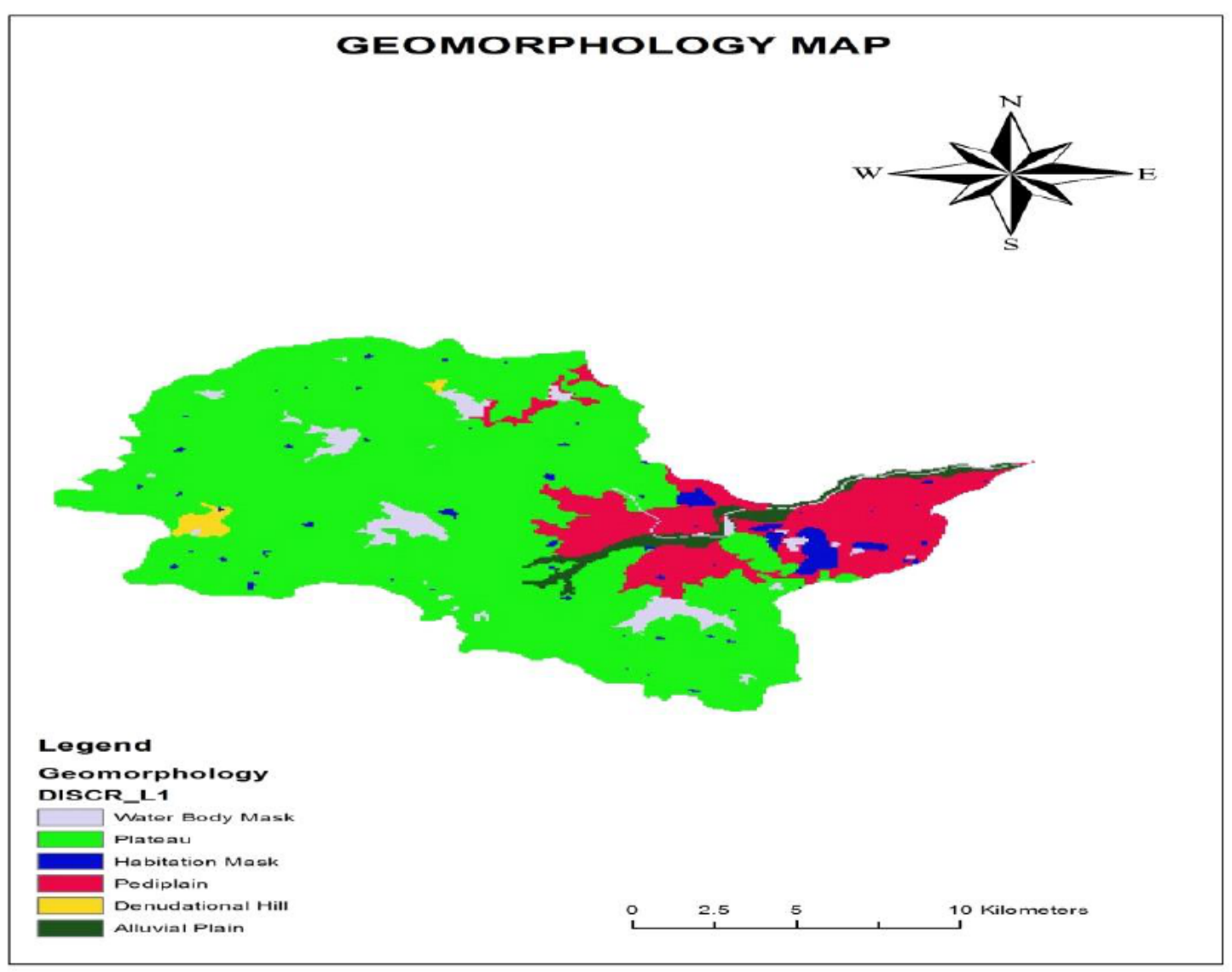

Figure 5 Geomorphology Map 
H.D.Bhave,. Y.B.Katpatal and Dr.A.M.Pophare

Table 4 Ranking for geomorphological units

\begin{tabular}{|c|c|c|c|}
\hline Sr. no & Geomorphological unit & $\begin{array}{c}\text { Ranking } \\
\text { (in word) }\end{array}$ & $\begin{array}{c}\text { Ranking } \\
\text { (in number) }\end{array}$ \\
\hline 1. & Pediplain & Good & 1 \\
\hline 2. & Plateau & Moderate & 2 \\
\hline 3. & Alluvial Plain & Moderate & 2 \\
\hline 4. & Habitation mask & Poor & 3 \\
\hline 5. & Denudational Hill & Poor & 3 \\
\hline 6. & Water body mask & Poor & 3 \\
\hline
\end{tabular}

\subsection{Soil}

The study area is prominently consisting in the basaltic region of Maharashtra and falls partly in the rocky hills and partly in black soil and alluvium soil. Alluvium soil is loose, unconsolidated soil or sediments, which has been eroded, reshaped by water in some form. These soils are considered as good for groundwater occurrence, holding and recharge potential. Regur soils are black in colour and are also known as black cotton soils. They are well-known for their ability to retain moisture. These soils have moderate effect as a controlling factor for groundwater occurrence and recharge potential for this study area. Mountain soils are mainly found in hill slopes. These are mostly less prone to infiltration and subsequently causing poor in groundwater occurrence and recharge potential. By extraction of various classes of soil types, a thematic map for soil was generated as per figure 6 . The ranks were assigned to the individual soil type, according to its respective influence of groundwater occurrence, holding and recharge as per table 5 below.

Table 5 Ranking of Soil types

\begin{tabular}{|c|c|c|c|c|}
\hline $\begin{array}{c}\text { Sr. } \\
\text { no. }\end{array}$ & Soil Types & $\begin{array}{c}\text { Ranking } \\
\text { (in words) }\end{array}$ & $\begin{array}{c}\text { Ranking } \\
\text { (in } \\
\text { number) }\end{array}$ \\
\hline 1. & & $\begin{array}{c}\text { Gravelly clay } \\
\text { loam }\end{array}$ & Good & 1 \\
\hline 2. & & Clay loam & Moderate & 2 \\
\hline 3. & & $\begin{array}{c}\text { Silty clay } \\
\text { loam }\end{array}$ & Moderate & 2 \\
\hline 4. & & $\begin{array}{c}\text { Gravelly } \\
\text { sandy clay } \\
\text { loam }\end{array}$ & Moderate & 2 \\
\hline 5. & & $\begin{array}{c}\text { Habitation } \\
\text { Mask }\end{array}$ & Poor & 3 \\
\hline 6. & & Clayey & Poor & 3 \\
\hline 7. & & $\begin{array}{c}\text { Waterbody } \\
\text { Mask }\end{array}$ & Poor & 3 \\
\hline
\end{tabular}




\section{SOIL MAP}
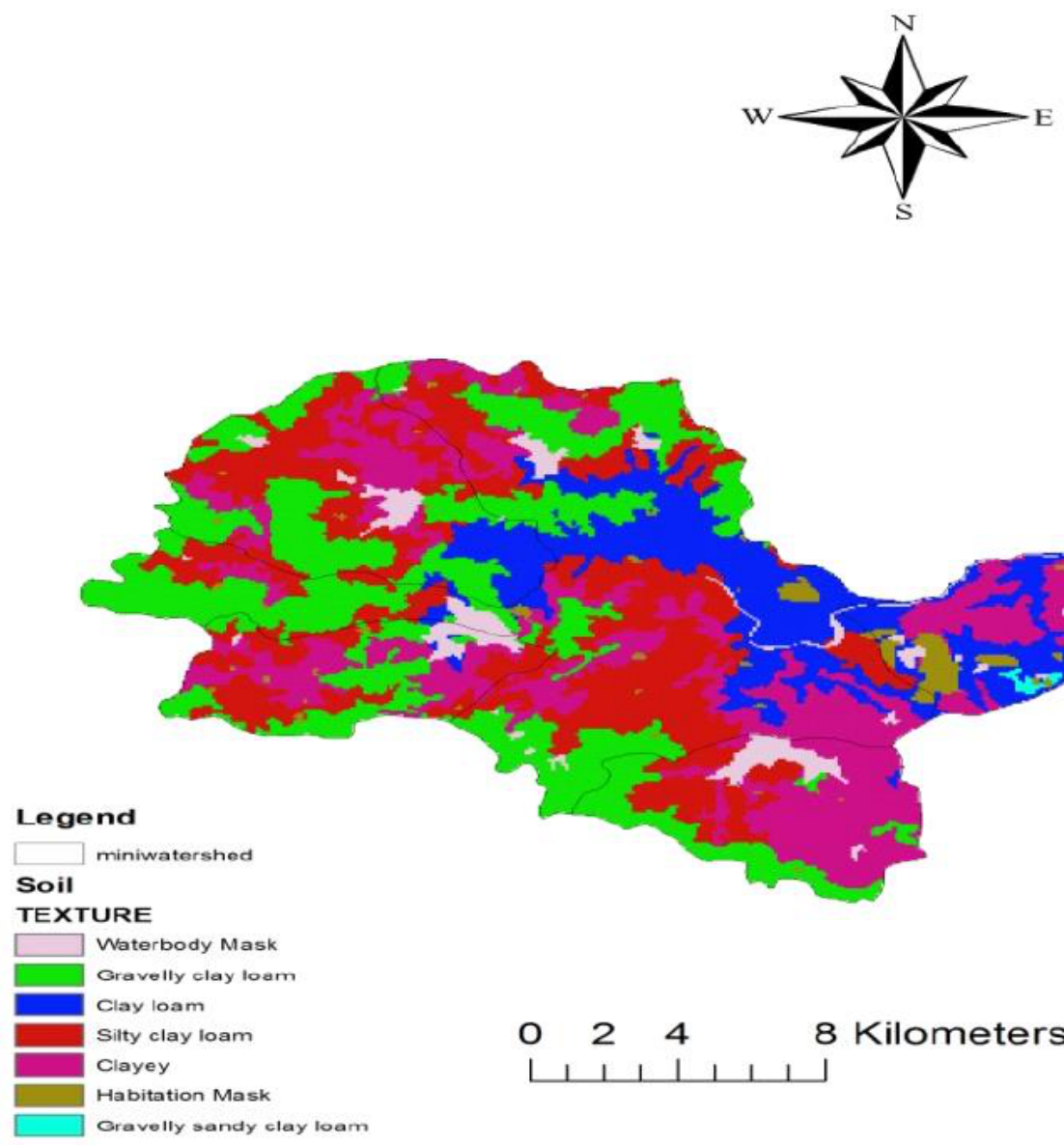

Figure 6 Thematic Map of Soil

\subsection{Land use land cover}

Land use land cover features control the occurrence of groundwater and also causes for infiltration for recharge, with variety of classes among itself. Remote sensing data and GIS technique provide reliable, accurate baseline information for land use land cover mapping, which plays vital role in determining land use pattern and changes therein on different times. The effect of land use land cover is manifested either by reducing runoff and facilitating, or by trapping water on their leaf. By extraction of various classes of land use land cover, a thematic map was generated as per figure 7 below. The ranks were assigned to the individual land use land cover type, according to its respective influence of groundwater occurrence, holding and recharge, as per table 6 below. 


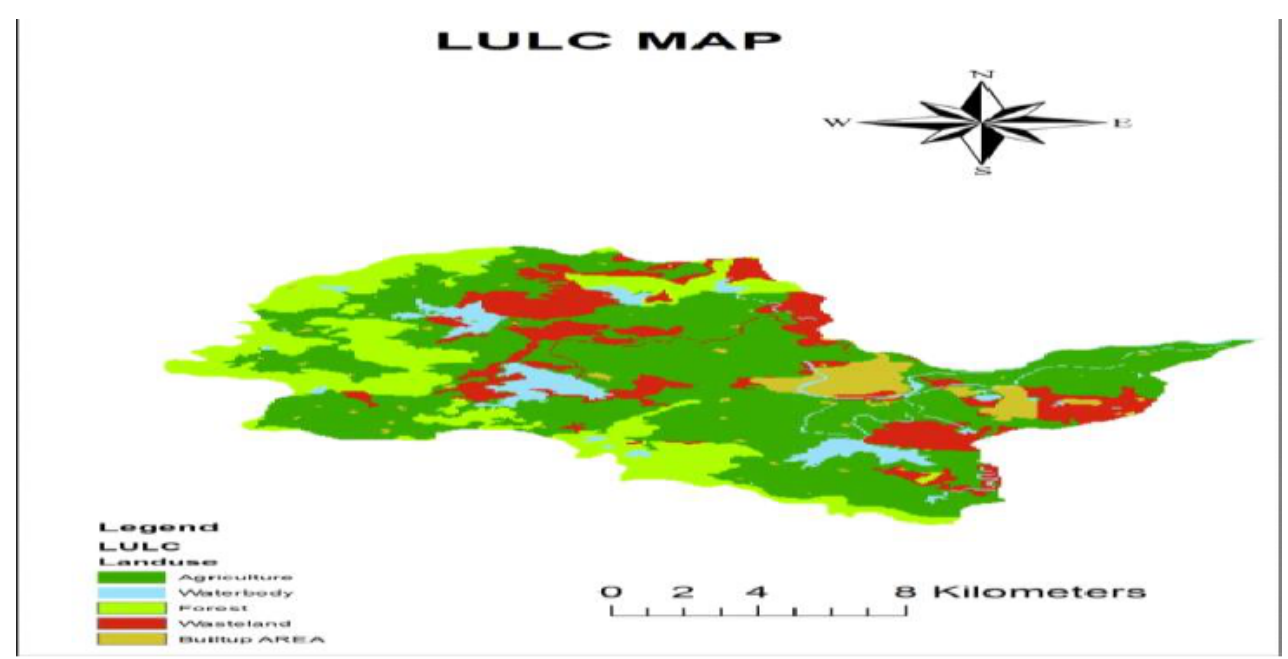

Figure 7 Map showing land use land cover feature

Table 6 Ranking for land use land cover

\begin{tabular}{|c|c|c|c|}
\hline Sr. no. & $\begin{array}{c}\text { Land use land } \\
\text { cover }\end{array}$ & $\begin{array}{c}\text { Ranking } \\
\text { (in words) }\end{array}$ & $\begin{array}{c}\text { Ranking } \\
\text { (in number) }\end{array}$ \\
\hline 1. & Agriculture & Good & 1 \\
\hline 2. & Forest & Moderate & 2 \\
\hline 3. & Wasteland & Moderate & 2 \\
\hline 4. & Waterbody & Poor & 3 \\
\hline 5. & Built-up area & Poor & 3 \\
\hline
\end{tabular}

\subsection{Lithology}

Variability in sediment hydraulic properties associated with landscape depositional and erosional features can influence groundwater recharge processes by affecting soil-water storage and transmission. This study considers recharge to aquifers underlying river-incised glaciated terrain where the distribution of clay-rich till is largely intact in upland locations but has been removed by alluvial erosion in stream valleys. The suitable ranks are assigned to the lithological units based on their influence in table 7 . The following figure 8 shows the map of the lithological feature.

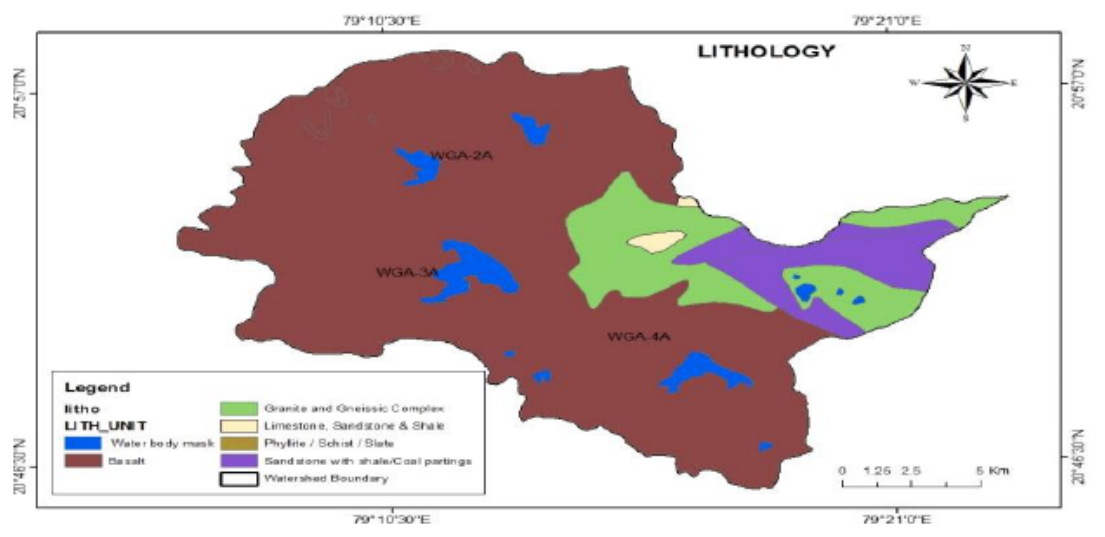

Figure 8 Map of lithological units 
Identification of Ground Water Recharge Potential Zone for Watershed using Gis And Remote Sensing

Table 7 Ranking of the lithological features

\begin{tabular}{|c|c|c|c|}
\hline $\begin{array}{c}\text { Sr. } \\
\text { no. }\end{array}$ & Lithology & $\begin{array}{c}\text { Ranking } \\
\text { (in words) }\end{array}$ & $\begin{array}{c}\text { Ranking } \\
\text { (in number) }\end{array}$ \\
\hline 1. & Limestone, Sandstone \& Shale & Good & 1 \\
\hline 2. & Sandstone with shale/Coal partings & Moderate & 2 \\
\hline 3. & Basalt & Moderate & 2 \\
\hline 4. & Granite and Gneissic Complex & Poor & 3 \\
\hline 5. & Water body mask & Poor & 3 \\
\hline
\end{tabular}

\subsection{Lineament}

Lineaments are linear geomorphic features that are the surface expression of zones of weakness or structural displacement in the crust of the earth. These are defined as the 'significant lines of landscape, which reveals the hidden architecture of the rock basement'. They are the character lines of the earth's physiognomy. Such features may represent deep seated faults, fractures and joints sets, drainage lines and boundary lines of different rock formations. All these linear features are interpreted from the satellite data and the lineament map is prepared for the study area. Lineaments are any linear features that can be picked out as lines in aerial or satellite imagery. From satellite imagery, lineament data is extracted and then lineament density map is generated, which is as per figure 9 below. Ranking as per lineament is shown in table 8

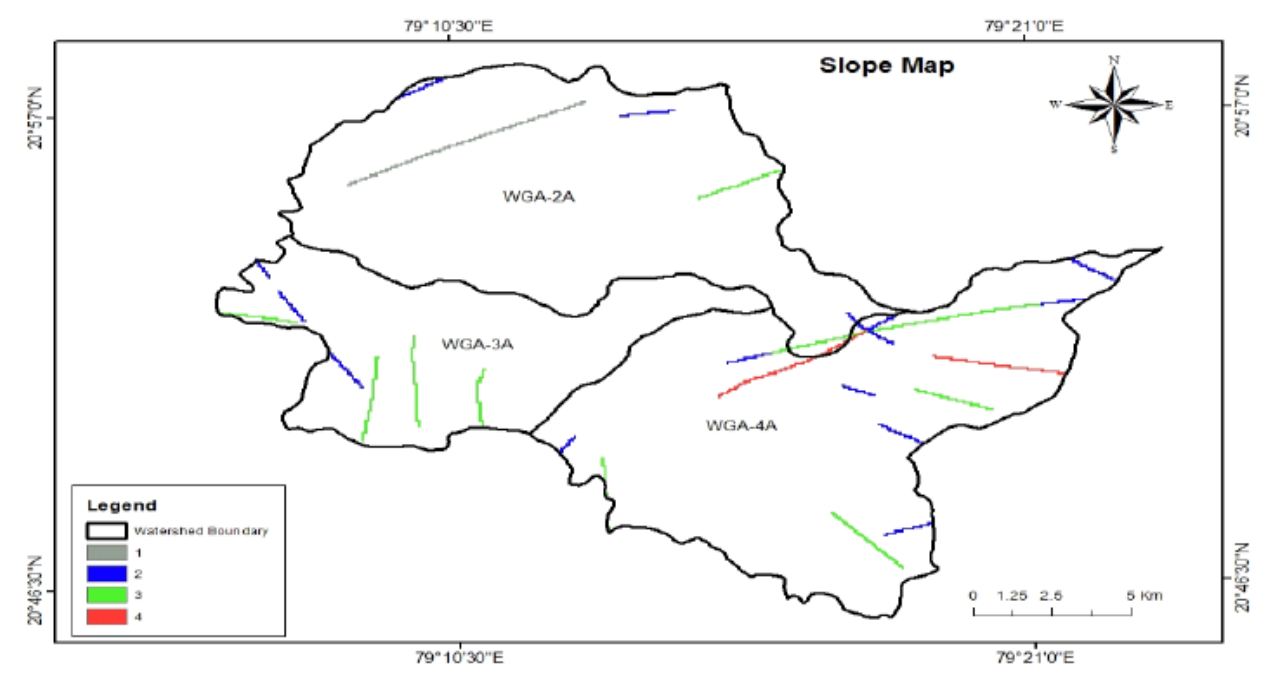

Figure 9 Map showing Lineament

Table 8 Ranking as per Lineament

\begin{tabular}{|c|c|c|c|}
\hline $\begin{array}{c}\text { Sr. } \\
\text { no. }\end{array}$ & $\begin{array}{c}\text { Lineament } \\
\text { value }\end{array}$ & $\begin{array}{c}\text { Ranking } \\
\text { (in words) }\end{array}$ & $\begin{array}{c}\text { Ranking } \\
\text { (in number) }\end{array}$ \\
\hline 1. & 4 & Good & 1 \\
\hline 2. & 3 & Moderate & 2 \\
\hline 3. & 2 & Moderate & 2 \\
\hline 4. & 1 & Poor & 3 \\
\hline
\end{tabular}




\subsection{Overlay analysis}

Overlay analysis is a multi-criteria analysis wherein analysis can be carried out with complex things for finding out certain theme with the help of assignment of rank to the individual class of feature and then assigning weightage to the individual feature considering its influence over theme. All the thematic maps were converted into raster format and superimposed by weighted overlay method, which consists of rank and weightage wise thematic maps and integration of them through GIS. Integration of thematic maps for carrying out multi-criteria or overlay analysis in GIS environment was done using ArcGIS software.

Ranking and weightages of parameters for groundwater recharge potential are shown in table 9

\section{RESULT}

This study analyzed the hydrologic and geographic attributes of the watershed in study area and identified six major factors influencing groundwater recharge potential, viz. Slope (\%), geomorphology, soil, land use land cover, lithology and lineament. Each factor was examined was assigned an appropriate weight. Each recharge potential factor may influence the groundwater recharge process to a different degree. Overlay analysis is carried out, using weighted overlay analysis tool provided in the ArcGIS software, to integrate various thematic maps viz. geomorphology map, soil map, slope (\%)map, land use land cover map, lithology map and lineament map, which are being very informative and plays important role in the study for groundwater recharge potential zones of study area. The various thematic maps were assigned with different weightages of numerical value to derive groundwater recharge potential zones. On the basis of weightage assigned to these maps and bringing them into the function of spatial analyst for integration of these thematic maps, a map indicating groundwater recharge potential zones is obtained, which is as per fig.10 below. This map has been categorized into three zones viz. 'least suitable', 'moderately suitable' and 'most suitable' from groundwater recharge potential point of view. The following table no.10gives the sum area for each type of the zone area.

\section{CONCLUSION}

This study proposed ground water recharge potential amplitude for above area. The results indicate that the most effective ground water recharge potential zone is located on WGA-2A part of the study area and WGA-3A is second in order of preference.In this region, the gravelly clay loam soil, pediplain and agricultural land and forest land have high infiltration ability. Also the concentration of drainage also indicates the ability of stream flow to recharge the groundwater system The southern region of study area is least effective for groundwater recharge, mainly due to its steep sloping topography .. The occurrence and recharge of groundwater in the study area is prominently controlled by the geomorphology, soil type, land use land cover and slope (\%) as revealed from GIS analysis. Remote sensing and GIS technique used to integrate various thematic maps proves to be very important to map the groundwater occurrence and movement for recharge potential mapping and management plan on a scientific basis. Overall result demonstrates that the use 
Identification of Ground Water Recharge Potential Zone for Watershed using Gis And Remote Sensing

Table 9 Ranking and weightages of parameters for groundwater recharge potential

\begin{tabular}{|c|c|c|c|}
\hline $\begin{array}{c}\text { GROUND WATER } \\
\text { RECHARGE POTENTIAL } \\
\text { FACTORS }\end{array}$ & CLASSES & RANK & $\begin{array}{c}\text { WEIGHTAGE } \\
\text { (\%) }\end{array}$ \\
\hline \multirow[t]{8}{*}{ Soil } & & & 25 \\
\hline & Waterbody Mask & 3 & \\
\hline & Gravelly clay loam & 1 & \\
\hline & Clay loam & 2 & \\
\hline & Silty clay loam & 2 & \\
\hline & Clayey & 3 & \\
\hline & Habitation Mask & 3 & \\
\hline & Gravelly sandy clay loam & 2 & \\
\hline \multirow[t]{6}{*}{ Lithology } & & & 15 \\
\hline & Basalt & 2 & \\
\hline & $\begin{array}{l}\text { Granite and Gneissic } \\
\text { Complex }\end{array}$ & 3 & \\
\hline & $\begin{array}{c}\text { Limestone, Sandstone \& } \\
\text { Shale }\end{array}$ & 1 & \\
\hline & Water body mask & 3 & \\
\hline & $\begin{array}{c}\text { Sandstone with shale/Coal } \\
\text { partings }\end{array}$ & 2 & \\
\hline \multirow[t]{6}{*}{ Land use \& Land cover } & & & 25 \\
\hline & Agriculture & 1 & \\
\hline & Waterbody & 3 & \\
\hline & Forest & 2 & \\
\hline & Wasteland & 2 & \\
\hline & Built up AREA & 3 & \\
\hline \multirow[t]{7}{*}{ Geomorphology } & & & 20 \\
\hline & Water Body Mask & 3 & \\
\hline & Plateau & 2 & \\
\hline & Habitation Mask & 3 & \\
\hline & Pediplain & 1 & \\
\hline & Denudational Hill & 3 & \\
\hline & Alluvial Plain & 2 & \\
\hline Slope & & & 10 \\
\hline
\end{tabular}


H.D.Bhave,. Y.B.Katpatal and Dr.A.M.Pophare

\begin{tabular}{|c|c|c|c|}
\hline (in degrees) & $0-3.1$ & 1 & \\
\hline & $3.2-5.7$ & 2 & \\
\hline & $5.8-9.1$ & 2 & \\
\hline & $9.2-16$ & 3 & \\
\hline & $17-47$ & 3 & \\
\hline & & & 5 \\
\hline Lineament & Low & 3 & \\
\hline & Moderate & 2 & \\
\hline & High & 2 & \\
\hline & Very high & 1 & \\
\hline
\end{tabular}

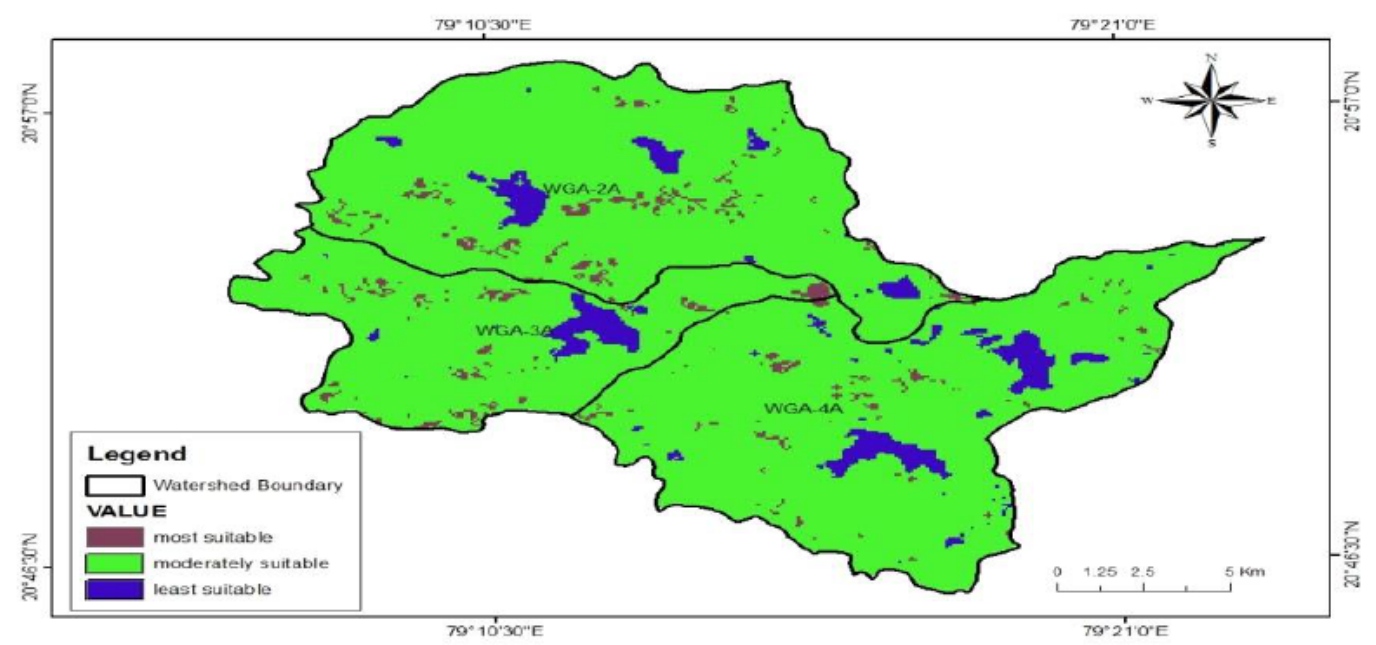

Figure 10 Ground water recharge potential zone map

Table 10 RESULTS

\begin{tabular}{|c|c|c|}
\hline Sr. no. & $\begin{array}{c}\text { Potential zone for } \\
\text { ground water } \\
\text { recharge }\end{array}$ & $\begin{array}{c}\text { Sum area } \\
\text { (in square } \\
\mathbf{k m} . \text { ) }\end{array}$ \\
\hline 1. & Most suitable & 8.743005 \\
\hline 2. & $\begin{array}{c}\text { Moderately } \\
\text { suitable }\end{array}$ & 309.0227 \\
\hline 3. & Least suitable & 16.90537 \\
\hline
\end{tabular}

Of remote sensing and GIS technique provides powerful tool to study groundwater resources and design a suitable exploration plan for recharge of groundwater in study area. The integrated groundwater recharge potential zones map for the study area has been categorized into three zones viz. 'least suitable', 'moderately suitable' and 'most suitable', on the basis of the ranks and weightages assigned to different features of the thematic maps. 
Identification of Ground Water Recharge Potential Zone for Watershed using Gis And Remote Sensing

\section{REFERENCES}

[1] Balachandar D., Alaguraja P., Sundaraj P., Rutharvelmurthy K. and Kumaraswamy K., "Application of Remote Sensing and GIS for Artificial Recharge Zone in Sivaganga District", International Journal of Geomatics and Geosciences, 1(1), 2010, pp 84-97

[2] Binay Kumar and Uday Kumar, Groundwater recharge zonation mapping and modelling using Geomatics techniques, International Journal of Environmental Sciences, 1(7), 2011, pp 16701681.

[3] Brema J. and Prince Arulraj G., Identification of sites suitable for artificial recharging and groundwater flow modeling in Noyyal river basin, Tamilnadu, India. International Journal of Sustainable Development, 3(8), 2012, pp 45-58

[4] Dandy Ahmad Yani, Mohammad Bisri, Lily Montarcih Limantara and Ery Suhartanto, Model Flood Peak Discharge Based on the Watershed Shape Factor, International Journal of Civil Engineering and Technology, 9(12), 2018, pp. 906-917
Central
Ground
Water
Board
$(\mathrm{cgwb})$ (http://cgwb.gov.in/District_Profile/Maharashtra/Nagpur.pdf)

[6] Chaudhary B. S., Manoj Kumar, Roy A. K. and Ruhal D. S., Applications of remote sensing and geographic information systems in groundwater investigations in Soha block, Gurgaon district, Haryana (India), International Archives of Photogrammetry and Remote Sensing, 31(B6), 1996, pp 18-23.

[7] Javed Akram and Mushtaq Hussain Wani, Delineation of groundwater potential zones in Kaknud Watershed, Eastern Rajasthan, Using Remote Sensing and GIS Techniques. Journal of Geological Society of India, 73(2), 2009, pp 229-236.

[8] Priyono Priyono, Rahayu Rahayu, Slamet Minardi and Suntoro Suntoro, Morphology of Landslide Prone of Agriculture Area in the Sub Watershed Samin Upstream Based on Landslide Type Used for Considerations of Early Mitigation Model, International Journal of Mechanical Engineering and Technology 9(7), 2018, pp. 462-475

[9] Jothiprakash V., Marimuthu G., Muralidharan R. and Senthilkumar N, Delineation of potential zones for artificial recharge using GIS. J. of Indian Society of Remote Sensing, 31(1),2003, pp 37-46.

[10] Jyotiswarup and Manish K. Tiwari,. Delineate groundwater prospect zones and identification of artificial recharge sites using geospatial technique, International Journal of Engineering, Science and Mathematics 2008,pp 1-15.

[11] Mishra Rajat C., Chandrasekhar Biju and Naik Ranjitsingh D, , Remote Sensing and GIS for Groundwater Mapping and Identification of Artificial Recharge Sites. GeoShanghai International Conference, 2010, pp 216-223.

[12] Eshanthini P, P. Vijayalakshmi, P.K. Raji, Rainfall Runoff Estimation Using SCS Model and Arc Gis for Micro Watershed in Cuddalore District. International Journal of Civil Engineering and Technology, 9(9), 2018, pp. 990-996

[13] Ranade Pinak., \& Katpatal, Y. B. Rainwater harvesting (RWH) potential assessment for microwatersheds in highly urbanized city using geo-spatial techniques. International Journal of Engineering and Applied Sciences (IJEAS) ISSN: 2394-3661, Volume-2, Issue-7, July 2015. 